Jurnal Akuntansi dan Investasi, Vol. 18 No. 2, Hlm: 153-162 Juli 2017

Artikel ini tersedia di website: http:/journal.umy.ac.id/index.php/ai

DOI: $10.18196 /$ jai. 180279

\title{
Modal Intelektual dan Daya Saing Perguruan Tinggi di Indonesia
}

\author{
Dwi Prihatni Amrih Rahayuningtyas* dan Eka Triana \\ Pascasarjana Ilmu Akuntansi, Universitas Indonesia, Jln. Prof. Dr. Sumitro Djojohadikusumo Depok, \\ Jawa Barat 16424 Indonesia
}

\begin{tabular}{l}
\hline A R T I C L E I N F O \\
\hline Article history: \\
received 15 Feb 2017 \\
revised 17 Apr 2017 \\
accepted 13 Jun 2017 \\
Keywords: \\
Intellectual Capital; \\
University; \\
Competitiveness; \\
Autonomy \\
\hline
\end{tabular}

A B S T R A C T
This study aims to examine the factors that affect the disclosure of intellectual
capital on universities in Indonesia, and how the influence of intellectual capital
disclosures on the competitiveness of higher education internationally. This study
uses 35 samples both public and private universities in Indonesia. This research use
linear regression and two stage least square to test the hyphoteses that processed by
Eviews.6. The results showed that the autonomy of the universities and colleges
rank previously have a significant impact on the disclosure of intellectual capital on
the official website of the universities. In addition, the disclosure of intellectual
capital has significant impact on the competitiveness of universities.

\section{PENDAHULUAN}

Perguruan tinggi di Indonesia pada tahun 2014 mencapai 4.270 yang terdiri dari sekolah tinggi, universitas, politeknik, akademi dan institut (Dirjen Pendidikan Tinggi, 2014). Peningkatan jumlah perguruan tinggi di Indonesia belum diikuti dengan peningkatan kualitas perguruan tinggi, hal ini ditandai dari rendahnya daya saing perguruan tinggi Indonesia di lingkup internasional. Berdasarkan peringkat perguruan tinggi yang dirilis oleh QS World University Ranking, pada tahun 2014 peringkat terbaik yang mampu dicapai perguruan tinggi di Indonesia adalah peringkat 310 yang diraih oleh Universitas Indonesia (UI), bahkan pada tahun 2015, peringkat yang dicapai justru menurun menjadi peringkat 358. Peringkat selanjutnya diraih oleh Institut Teknologi Bandung (ITB) yang menduduki peringkat pada rentang 461 sampai 470, peringkat tersebut tidak mengalami perubahan dibandingkan tahun sebelumnya.

Proses pemeringkatan tersebut diolah oleh QS World University Ranking dengan melakukan perbandingan antar 3000 lebih universitas di dunia dalam hal penelitian, pengajaran, kemampuan pendidik maupun tenaga pendidikan serta wawasan internasional. Penelitian ini menggunakan pengukuran peringkat dengan $Q S$ World University Ranking karena dinilai mampu mem- berikan pengetahuan mendalam bagi calon mahasiswa untuk mengidentifikasi kelebihan sebuah universitas (Pratiwi, 2012).

Perguruan tinggi menghadapi persaingan sebagaimana entitas bisnis pada umumnya. Beberapa persaingan yang dihadapi oleh perguruan tinggi yaitu pertumbuhan perguruan tinggi, menarik minat calon mahasiswa dan profesor sebagai pendidik serta penggalangan dana. Salah satu mekanisme perguruan tinggi dalam menghadapi persaingan tersebut adalah dengan menampilkan keunggulan maupun sumberdaya yang dimiliki (Constantin, 2005). Sumberdaya atau aset yang paling berharga yang dimiliki perguruan tinggi adalah para pendidik dan mahasiswa yang berintegrasi membentuk organisasi. Keunggulan atas aset inilah yang menjadi pembanding antar perguruan tinggi. Aset utama tersebut tidak dapat teridentifikasi secara nyata, sehingga disebut aset tidak berwujud.

Aset tidak berwujud yang menjadi keunggulan kompetitif pada perguruan tinggi dapat diperoleh dengan cara berinovasi, menerapkan inisiatif baru serta kemampuan menjalin hubungan positif dengan pemangku kepentingan (stakeholder) (Fazlagic dan Skikiewicz, 2014). Cara-cara tersebut merupakan nilai yang diperoleh dari kemampuan organisasi dalam menerjemahkan pengetahuan yang dimilikinya. Kemampuan tersebut didefinisikan sebagai modal intelektual (inte- 
Ilectual capital) yang selanjutnya disebut dengan MI (Fazlagic dan Skikiewicz, 2014).

Pengetahuan, inovasi dan modal intelektual dalam suatu perguruan tinggi menjadi mekanisme tersendiri bagi negara-negara yang bertujuan membangun keunggulan kompetitif yang berkelanjutan (Chen dan Chen, 2013). Modal intelektual dipercaya dapat memperkuat kemampuan inovatif sehingga keunggulan kompetitif dapat tercapai. Ekonomi berbasis pengetahuan (knowledge-based economy) mendorong meningkatnya partumbuhan modal intelektual (Wu et al., 2010 dalam Chen dan Chen, 2013). Pada saat ini, penelitian yang meneliti knowledge management dan modal intelektual lebih banyak dilakukan dalam konteks perusahaan bisnis, namun ketertarikan organisasi publik seperti universitas dan pusat penelitian menunjukkan peningkatan (Constantin, 2005).

Rendahnya daya saing perguruan tinggi dalam lingkup internasional mendorong pentingnya reformasi pada pengelolaan perguruan tinggi di Indonesia. Guna penyelenggaraan perguruan tinggi yang lebih baik, maka perguruan tinggi memiliki otonomi dalam mengelola organisasinya. Otonomi perguruan tinggi di Indonesia diatur dalam Undang-undang No 12 tahun 2012 mengenai pendidikan tinggi. Meskipun setiap perguruan tinggi memiliki otonomi akan tetapi pengelolaannya harus memenuhi prinsip akuntabilitas, transparansi, nirlaba, penjaminan mutu serta efektivitas dan efisiensi. Transparansi pada perguruan tinggi salah satunya adalah melalui pengungkapan informasi (Shanchez dan Elena, 2006). Pengungkapan informasi sangat penting bagi regulator, standar akuntansi, investor dan konsumen (Debreceny et al., 2002). Pada saat ini, pengungkapan informasi banyak dilakukan melalui internet yang berkembang sangat pesat. Metode pengungkapan berpengaruh dalam peningkatan permintaan informasi oleh stakeholder baik informasi finansial maupun non finansial.

Selain transparansi, peningkatan daya kompetitif perguruan tinggi didukung dengan pemberian otonomi pada perguruan tinggi, berdasarkan UU No. 12 Tahun 2012 tentang pendidikan tinggi. Kualitas otonomi yang dimiliki perguruan tinggi berdasarkan penelitian Sanchez et al. (2009) menunjukkan bahwa saat ini diperlukan adanya kebebasan dan kreatifitas dalam memadukan pembiayaan yang berasal pemerintah dan dana publik. Selain itu, penelitian Chen dan Chen (2013) mengungkapkan bahwa peringkat yang telah dicapai sebelumnya mendorong perguruan tinggi untuk mempertahankan pencapaian tersebut melalui pengungkapan MI.

Fokus utama penelitian ini adalah pengungkapan MI dan bagaimana dampaknya terhadap daya saing pada perguruan tinggi. Penelitian MI di perguruan tinggi sangat penting dilakukan karena perguruan tinggi memiliki peran sebagai produsen dan penyebar ilmu pengetahuan (Canibano dan Sanchez, 2009). Jumlah penelitian mengenai pengungkapan MI pada perguruan tinggi di Indonesia masih sangat sedikit dan masih berfokus pada analisis deskriptif pengungkapan MI doleh perguruan tinggi, dan jarang yang meneliti keterkaitan antara MI dengan variabel lainnya, misalnya kualitas atau daya saing perguruan tinggi. Berangkat dari research gap tersebut, maka penelitian ini bertujuan untuk meneliti pengaruh pengungkapan MI pada situs perguruan tinggi, yaitu otonomi dan peringkat perguruan tinggi yang telah dicapai sebelumnya, dan menguji pengaruh pengungkapan MI di perguruan tinggi terhadap daya saing perguruan tinggi secara internasional.

Secara teoritis, penelitian ini memberikan bukti empiris bahwa otonomi dan peringkat perguruan tinggi yang telah dicapai sebelumnya berperan dalam pengungkapan MI pada perguruan tinggi di Indonesia, dan MI berperan dalam peningkatan daya saing perguruan tinggi. Secara praktis, penelitian ini memberikan tambahan informasi bagi perguruan tinggi maupun pemerintah bahwa MI mampu meningkatkan daya saing perguruan tinggi Indonesia secara internasional, sehingga dapat dijadikan dasar dalam pembuatan kebijakan terkait fokus pada pengelolaan dan pengungkapan MI bagi banyak perguruan tinggi di Indonesia.

\section{TINJAUAN LITERATUR DAN PERUMUSAN HIPOTESIS}

\section{Teori Pensinyalan}

Teori pensinyalan sangat terkait dengan pengungkapan MI (Connelly et al., 2011). Pengungkapan MI menjadi salah satu mekanisme untuk menurunkan adanya asimetri informasi antara pihak internal dan eksternal organisasi. Pemberian informasi relevan yang memadai bagi pihak yang berkepentingan meningkatkan pemahaman yang sama. Tujuan pengungkapan MI bagi pihak yang berkepentingan adalah meningkatkan kemampuan evaluasi atas potensi yang dimiliki perguruan tinggi berdasarkan kompetensi pergu- 
ruan tinggi yang tercermin dari modal intelektualnya.

Teori pensinyalan dapat meningkatkan pemahaman mengenai pengungkapan MI pada perguruan tinggi. Teori sinyal menyatakan bahwa perusahaan memberikan sinyal positif pada investor dan pemangku kepentingan lainnya melalui laporan tahunan dan laporan tambahan melalui pengungkapan (Connelly et al., 2011). Adanya pengungkapan informasi entitas, membantu para pemangku kepentingan menilai masa depan entitas dalam menciptakan nilai melalui pengelolaan MI secara tepat (Holmen, 2011). Secara tidak langsung pengungkapan MI pada perguruan tinggi dapat meningkatkan minat calon mahasiswa maupun lembaga penelitian untuk bekerjasama dengan perguruan tinggi. Perguruan tinggi mengkomunikasikan keunggulan kompetitif yang diperoleh melalui pengungkapan MI.

\section{Pengungkapan MI pada Perguruan Tinggi}

Pada perguruan tinggi, MI mengacu pada semua aset tidak berwujud yang dimiliki lembaga, meliputi proses, kapasitas inovasi, paten, pengetahuan yang dimiliki anggotanya, bakat, keterampilan, pengakuan dari masyarakat, jaringan kerjasama dan lain-lain (Corcolez et al., 2011). Pelaporan MI adalah pendekatan yang digunakan untuk mengukur aset tidak berwujud guna menggambarkan hasil dari usaha yang berbasis aktivitas pengetahuan (knowledge-based activities) karena stakeholder perguruan tinggi menekankan perlunya informasi MI guna membuat keputusan yang tepat, sehingga transparansi perguruan tinggi atas sumberdaya intelektual yang dimiliki sangat diperlukan (Bornermann dan Leitner, 2002). Peningkatan permintaan informasi dan transparansi perguruan tinggi oleh pemangku kepentingan, disebabkan persaingan yang dihadapi perguruan tinggi yang semakin ketat sehingga perguruan tinggi dituntut untuk mengkomunikasikan hasil-hasil yang telah dicapai (Ramirez dan Gordillo, 2014).

Peraturan akuntansi membatasi adanya pengakuan aset tidak berwujud, sehingga badan internasional, lembaga dan institusi akademik cenderung melaporkan MI yang dimiliki melalui publikasi laporan MI yang terdiri dari visi organisasi, ringkasan aset tak berwujud dan indikator. Informasi laporan secara berkelanjutan diungkapkan oleh perguruan tinggi baik melalui laporan keuangan dan laporan tahunan, juga melalui situs perguruan tinggi. Pada dasarnya komponen MI antar negara dan antar perguruan tinggi berbeda-beda. Komponen MI di Indonesia salah satunya dikembangkan dalam penelitian Ulum (2012) yang didasarkan pada komponen yang telah diteliti oleh Leitner (2002) di Eropa dan dikolaborasi dengan standar dan prosedur akreditasi Dikti. Komponen hasil adaptasi pada Ulum (2012) antara lain: modal manusia, modal struktural dan modal relasional.

\section{Otonomi Perguruan Tingi dan Pengungkapan MI}

Tuntutan reformasi pada pendidikan tinggi memunculkan adanya peningkatan otonomi dalam penyelenggaraan perguruan tinggi yang dikelola pemerintah. Perguruan tinggi di Indonesia menurut UU No. 12 Tahun 2012 Tentang Pendidikan Tinggi, berdasarkan penyelenggaranya dibagi menjadi 2, yaitu perguruan tinggi negeri (PTN) dan perguruan tinggi swasta (PTS). Pada PTN, pengelolaan keuangannya digolongkan menjadi 2, yaitu PTN Badan Hukum (PTN BH) dan PTN Badan Layanan Umum (PTN BLU). Berdasarkan UU tersebut, otonomi perguruan tinggi dilaksanakan berdasarkan prinsip akuntabilitas, transparansi, nirlaba, penajaminan mutu serta efektivitas dan efisiensi.

Otonomi pada perguruan tinggi bertujuan supaya perguruan tinggi mengelola sendiri lembaganya sehingga meningkatkan pengembangan ilmu pengetahuan dan teknologi guna memajukan bangsa (UU No. 12 Tahun 2012). PTN BH mempunyai tingkat otonomi yang lebih luas daripada PTN BLU, tetapi ditetapkan bahwa tingkat akuntabilitas, transparansi serta efektivitas dan efisiensinya lebih tinggi daripada PTN BLU. Sedangkan pada PTS, tingkat otonomi yang dimiliki diatur oleh badan penyelenggara berdasarkan perundang-undangan yang berlaku.

Otonomi yang dimiliki PTN BH berpengaruh pada kewenangan untuk mengatur organisasi, jika dibandingkan dengan PTN BLU atau satuan kerja, diantaranya kewenangan membuka dan menutup program studi serta leluasa dalam menjalin kerjasama dan usaha, serta keleluasaan mengelola pendapatan sendiri (Situs Kemendikbud Kopertis XII, 2013). Adanya otonomi yang dimiliki perguruan tinggi, memberikan keleluasaan perguruan tinggi untuk mengkombinasikan dana pemerintah dan dana publik (Sanchez et al., 2009). Dalam usahanya memperoleh dana publik, perguruan tinggi memberikan informasi bagi pemangku kepentingan, baik berupa informasi keuangan maupun non keuangan 
yang bertujuan memberikan sinyal bahwa perguruan tinggi telah dikelola dengan baik. Salah satu upaya perguruan tinggi dalam memberikan sinyal positif tersebut adalah melalui pengungkapan informasi non keuangan, yakni MI.

Pengungkapan MI menjadi sinyal yang dapat meningkatkan pengetahuan pihak yang berkepentingan atas sumber daya utama yang dimiliki oleh perguruan tinggi. Pemangku kepentingan diharapkan tertarik untuk bekerjasama dengan perguruan tinggi, baik dalam hal terjalinnya kerjasama dalam bentuk pendanaan maupun ketertarikan staf pengajar yang berkualitas untuk bergabung dengan perguruan tinggi. Peningkatan dana yang diperoleh perguruan tinggi dan adanya otonomi yang dimiliki meningkatkan keleluasaan perguruan tinggi dalam mengkombinasikan dana publik dan pemerintah. Berdasarkan hal tersebut, hipotesis penelitian ini adalah:

$\mathrm{H}_{1}$ : Otonomi perguruan tinggi berpengaruh positif terhadap pengungkapan MI pada situs resmi perguruan tinggi.

\section{Peringkat Perguruan Tinggi dan Pengungkapan MI}

Modal intelektual dapat meningkatkan kinerja dan daya saing organisasi, karena keberadaan MI menyebabkan perguruan tinggi mempunyai fokus dalam beraktivitas mengelola sumberdaya yang dimiliki sehingga mampu bertahan dalam lingkungan berbasis pengetahuan yang cepat mengalami perubahan (Secundo et al., 2010 sebagaimana dikutip oleh Fazlagic dan Skikiewicz, 2014). Pengetahuan, inovasi dan MI sangat erat kaitannya dengan perguruan tinggi yang digunakan untuk membangun keunggulan kompetitif berkelanjutan. Klaim tersebut mendukung penelitian bahwa peringkat/ ranking perguruan tinggi berelasi dengan persepsi MI (Chen dan Chen, 2011).

Berdasarkan beberapa penelitian terdahulu tersebut, diperoleh dugaan bahwa bahwa MI merupakan sarana perguruan tinggi untuk mempertahankan peringkat yang diperoleh sebelumnya, sehingga perguruan tinggi akan terus meningkatkan publikasi MI yang dimiliki pada situs resmi yang dimiliki. Berdasarkan pemaparan sebelumnya, maka hipotesis kedua adalah:

$\mathrm{H}_{2}$ : Peringkat perguruan tinggi yang telah diumumkan sebelumnya berpengaruh positif terhadap pengungkapan MI pada situs resmi perguruan tinggi.

\section{Daya Saing Perguruan Tinggi}

Modal intelektual dapat meningkatkan kinerja dan daya saing organisasi, karena keberadaan MI menyebabkan perguruan tinggi mempunyai fokus dalam beraktivitas mengelola sumberdaya yang dimiliki sehingga mampu bertahan dalam lingkungan berbasis pengetahuan yang cepat mengalami perubahan (Secundo et al., 2010 sebagaimana dikutip Fazlagic dan Skikiewicz, 2014). Selain itu, pengungkapan MI juga berdampak positif pada kinerja perguruan tinggi saat ini (Meilianti dan Frisko, 2013). Berdasarkan penelitian sebelumnya, maka hipotesis ketiga penelitian ini adalah:

$\mathrm{H}_{3}$ : Pengungkapan MI pada situs perguruan tinggi berpengaruh positif terhadap daya saing yang dicapai.

\section{METODE PENELITIAN}

\section{Sampel}

Sampel penelitian ini adalah perguruanperguruan tinggi yang berkedudukan di Indonesia, dan diplih berdasarkan peringkat yang dirilis oleh Webometrics tahun 2014/2015. Jumlah perguruan tinggi yang digunakan adalah perguruan tinggi dengan peringkat 1 sampai dengan 35. Digunakannya sampel dengan jumlah tersebut dilatarbelakangi oleh hanya sejumlah 35 perguruan tinggi yang di Indonesia yang mengungkapkan data berkaitan dengan MI di websitenya secara cukup lengkap.

\section{Jenis dan Sumber Data}

Data yang digunakan pada penelitian ini adalah data sekunder yang diperoleh melalui situs resmi perguruan tinggi baik PTN maupun PTS di Indonesia. Pengumpulan data pengungkapan MI dilaksanakan pada 31 Maret 2015 sampai dengan 4 April 2015. Data pengungkapan MI tersebut baik yang telah disediakan di situs secara langsung maupun melalui berita yang dirilis oleh situs perguruan tinggi sampel. Pengungkapan MI pada perguruan tinggi berdasarkan komponen MI dari penelitian Ulum dan Novianty (2012) yang diadaptasi dari penelitian Leitner (2002). Data lain yang digunakan dalam penelitian ini adalah tingkat otonomi perguruan tinggi, lokasi, peringkat perguruan tinggi berdasarkan QS-Star, dan umur perguruan tinggi yang juga diperoleh dari internet. Peng- 
umpulan data dilaksanakan pada akhir Maret 2015 .

\section{Pengukuran Variabel}

\section{Pengungkapan Modal Intelektual}

Metode penghitungan MI dilakukan dengan analisis konten lalu memberikan cek list atas pengungkapan MI pada situs resmi perguruan tinggi. Indikator pengukuran MI meliputi human capital, structural capital, dan relational capital yang terdiri dari 46 komponen mengacu pada penelitian Ulum dan Novianty (2012) dan Pratiwi (2012).

\section{Daya saing/Competitive Advantage}

Daya saing diukur berdasarkan peringkat terbaru yang diperoleh oleh perguruan tinggi berdasarkan peringkat $Q S$ World 2015. Penggunaan indeks $Q S$ World sebagai proksi daya saing (Competitive Advantage) perguruan tinggi karena lembaga ini melakukan penilaian secara lebih mendalam berdasarkan kualitas universitas mencakup; jumlah mahasiswa, banyaknya program studi, serta jumlah riset dan publikasi yang terindeks di jurnal maupun simposium yang dinilai bereputasi baik secara internasional.

\section{Otonomi Perguruan Tinggi}

Otonomi yang dimiliki PTN BH berpengaruh pada kewenangan untuk mengatur organisasi, jika dibandingkan dengan PTN BLU atau satuan kerja, diantaranya kewenangan membuka dan menutup program studi serta leluasa dalam menjalin kerjasama dan usaha, serta keleluasaan mengelola pendapatan sendiri (Situs Kemendikbud Kopertis XII, 2013). Berdasarkan UU No. 12 tahun 2012 perihal pendidikan tinggi yang membedakan kategori perguruan tinggi menjadi tiga, yakni; (1) PTN yang penyelenggaraan kegiatannya diatur dengan Peraturan Menteri; (2) PTN Badan Hukum yang ditetapkan dengan Peraturan Pemerintah; dan (3) PTS yang diatur oleh Badan Penyelengggara. Karenanya, pengukuran tingkat otonomi perguruan tinggi berdasarkan pengelolaan perguruan tinggi dihitung dengan poin 2 untuk PTN BH, 1 untuk PTS dan 0 untuk PTN BLU. Selain itu, penggunaan ukuran tersebut mengacu pada kualitas otonomi yang dimiliki perguruan tinggi berdasarkan penelitian Sanchez dkk (2009) bahwa saat ini diperlukan adanya perpaduan dalam hal pembiayaan antara pemerintah dan dana publik.

\section{Peringkat Perguruan Tinggi}

Peringkat perguruan tinggi diperoleh dari data QS-Star yang dirilis pada awal 2015. Pengukuran menggunakan skala dummy dengan nilai 1 jika termasuk dalam peringkat 8 besar dan 0 jika sebaliknya.

\section{Variabel Kontrol}

\section{Lokasi Perguruan Tinggi}

Pemerataan perguruan tinggi saat ini tidak merata, di mana Pulau Jawa mempunyai kualitas perguruan tinggi yang lebih tinggi jika dibandingkan dengan daerah lain di Indonesia (Kompas, 2015). Kualitas tersebut terukur dari sedikitnya jumlah program studi pada perguruan tinggi di luar Jawa yang memperoleh akreditasi A dari Badan Akreditasi Nasional Perguruan Tinggi (BAN-PT). Berdasarkan data yang diperoleh dari BAN-PT, terdapat 223 program studi di luar Jawa dengan akreditasi A dan sedangkan di Pulau Jawa jumlah program studi yang mencapai akreditasi A berjumlah 1.478. Hal ini menyebabkan tingkat persaingan antara perguruan tinggi di Pulau Jawa dan di luar Pulau Jawa berbeda. Mutu perguruan tinggi yang tidak merata disebabkan kualitas sumber daya manusia penduduk Indonesia yang tidak merata.

Pemanfaatan informasi MI memungkinkan perguruan tinggi meningkatkan keunggulan kompetitif yang dimiliki, misalnya pemberian pelayanan pendidikan yang lebih menarik dan sesuai kebutuhan akademisi serta kualitas dan teknik pembelajaran yang meningkatkan kualitas lulusan perguruan tinggi sehingga pangsa pasar yang diperoleh menjadi lebih luas dibanding pesaing (Porter, 2006; Hall, 1993 dalam Fazlagic dan Skikiewicz, 2014). Pengukuran skala dummy digunakan untuk mengukur lokasi perguruan tinggi. Perguruan tinggi yang berlokasi di Pulau Jawa diberi nilai 1 dan 0 jika sebaliknya.

\section{Umur Perguruan Tinggi}

Penelitian mengenai umur perguruan tinggi yang relevan dengan pengungkapan MI saat ini belum terdukung (Ulum dan Novianty, 2012). Referensi yang diambil dalam penelitian ini berasal dari industri yang relevan dengan 
perguruan tinggi yaitu penelitian pada perusahaan yang berbasis pegetahuan dan teknologi. Salah satunya penelitian Sonnier et al. (2009) di Amerika yang meneliti karakteristik perusahaan terhadap pengungkapan MI pada perusahaan yang berkonsentrasi pada industri high tech. Karakteristik yang diteliti antara lain umur dan ukuran perusahaan yang dicerminkan dari jumlah pegawai dan total aset. Dari penelitian tersebut, ditemukan bukti bahwa umur perusahaan berpengaruh signifikan terhadap pengungkapan MI sedangkan ukuran perusahaan tidak berpengaruh.

Data umur perguruan tinggi diperoleh berdasarkan data dari internet berdasarkan peringatan dies natalis yang diperingati perguruan tinggi, data diperoleh dari internet maupun situs resmi perguruan tinggi dan berita yang dirilis oleh situs perguruan tinggi sampel. Umur perguruan tinggi memperhitungkan peringatan dies natalis sebelum Maret 2015, akan tetapi, jika peringatan dies natalis setelah Maret, menggunakan umur pada tahun 2014.

\section{Analisis Data}

\section{Analisis Tingkat Pengungkapan MI}

Data pengungkapan MI diperoleh dengan melakukan analisis pada situs resmi perguruan tinggi dan berita yang dirilis situs tersebut. Analisis dilakukan dengan cara memberikan nilai 1 pada komponen MI yang ada di situs, dan diberi nilai 0 jika tidak mengungkapkan. Keterbatasan penelitian ini adalah proses pengumpulan data dalam tempo yang singkat, sedangkan sebenarnya dalam pengklasifikasian diperlukan waktu yang lama dan proses yang berulang-ulang guna meningkatkan keakuratan data (Ulum dan Novianty, 2012).

\section{Analisis Regresi}

Analisa korelasi regresi berganda digunakan dalam menguji faktor-faktor yang mempengaruhi pengungkapan MI perguruan tinggi pada situs resmi yang dimiliki, yakni otonomi dan peringkat sebelumnya dari perguruan tinggi sampel. Regresi dilakukan dengan menggunakan software EViews 6.0. pada 35 perguruan tinggi sampel. Data variabel dependen dan independen adalah data type undated dengan total observasi sebanyak 35 data. Metode yang digunakan adalah metode regresi linier dan two stage least square. Model yang digunakan dalam penelitian ini adalah sebagai berikut:

\section{Model 1: DISCMI $=\boldsymbol{\alpha}+\boldsymbol{\beta} 1 \mathrm{OTO}+\boldsymbol{\beta} 2 \mathrm{LOC}+$ $\beta 3 \mathrm{RANK}+\beta 4 \mathrm{AGE}+\varepsilon$}

\section{Model 2: COMP $\quad=\alpha+\beta 1 D I S C M I+\varepsilon$}

Keterangan :

COMP: Daya saing perguruan tinggi, menggunakan 9 peringkat yang diperoleh dari QS World. Peringkat 1 dengan poin 9, peringkat ke 2 diberikan poin 8, dan seterusnya

DISCMI: Pengungkapan modal Intelektual

OTO: Tingkat otonomi perguruan tinggi berdasarkan pengelolaannya

RANK: Peringkat perguruan tinggi yang dirilis sebelumnya, 1 jika termasuk dalam peringkat QS-Star dan 0 jika sebaliknya

LOC: Lokasi perguruan tinggi, 1 jika di Pulau Jawa dan 0 jika sebaliknya

AGE: Umur perguruan tinggi berdasarkan peringatan dies natalis yang diselenggarakan.

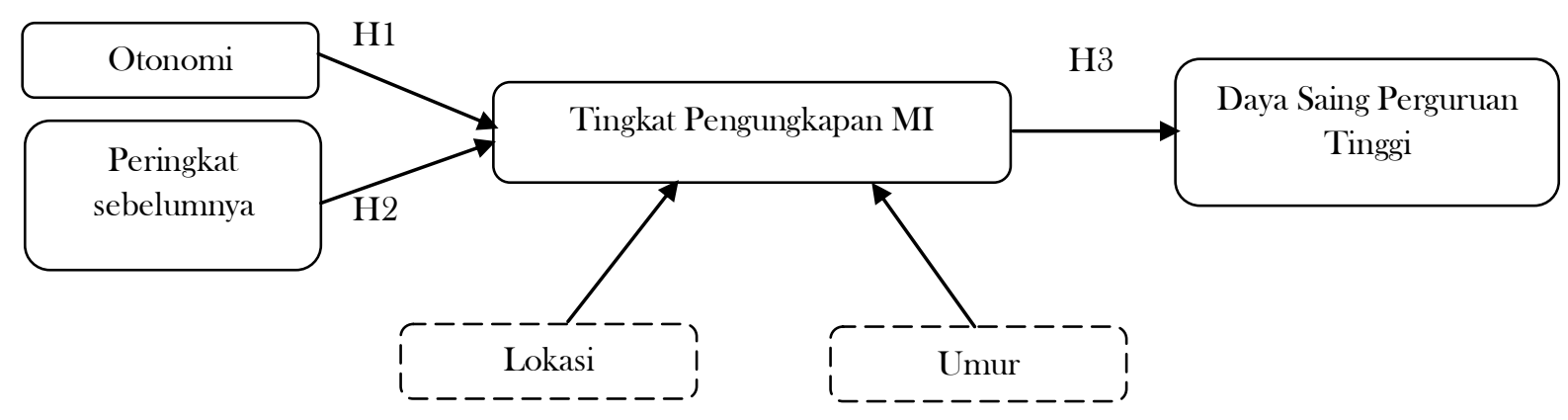

Gambar 1. Model Penelitian 


\section{HASIL DAN PEMBAHASAN}

\section{Statistik Deskriptif dan Ringkasan Data}

Hasil statistik deskriptif (lihat Tabel 1) menunjukkan bahwa rata-rata pengungkapan MI oleh 35 perguruan tinggi sampel sebanyak 27,91 item, dengan nilai tengah pengungkapan 28 dan tercatat bahwa item MI paling banyak diungkapkan mencapai 35 item dan paling sedikit 16 item dari keseluruhan 46 item MI. Standar deviasi pengungkapan MI sebesar 4,64. Rata-rata umur perguruan tinggi adalah 49,48 tahun dengan nilai tengah 54 tahun, perguruan tinggi paling tua berusia 70 tahun dan paling muda berusia 11 tahun dan standar deviasi umur adalah 13,40. Sedangkan variabel otonomi menunjukkan ratarata tingkat otonomi perguruan tinggi adalah 0,9 dengan standar deviasi 0,85307. Variabel dummy lokasi menunjukkan standar deviasi 0,4 dan variabel peringkat berdasarkan QS-Star sebesar 0,458. Sedangkan daya saing diukur dengan peringkat 1 yang menjadi maksimum dan minimum 0 jika tidak memperoleh peringkat.

\section{Hasil Analisis Regresi}

Uji multikolinearitas digunakan dalam penelitian ini untuk menguji ada atau tidaknya korelasi antar variabel indepeden yang dapat menyebabkan hasil penelitian menjadi bias (lihat Tabel 3). Hasil uji multikolinearitas menunjukkan bahwa antara variabel independen tidak ditemukan adanya korelasi.

Selain meguji korelasi antar variabel, data dari penelitian juga diuji apakah ada heteroskedastisitas, guna menguji apakah eror yang muncul akan berelasi dengan variabel dependen yang menyebabkan varian menjadi lebih besar. Heteroskedastisitas diuji dengan menggunakan Breusch-Pagan-God-frey. Hasil uji heterokedastis pada dampak tingkat otonomi, peringkat sebelumnya, lokasi dan umur perguruan tinggi terhadap pengungkapan MI menunjukkan bahwa secara keseulurahan data tidak berkorelasi dengan eror, hal ini tercermin pada scale explained $S \boldsymbol{S}$ yang lebih besar dari alfa $(1,957>0,05)$.

Hasil uji heteroskedastisitas pada dampak pengungkapan MI terhadap daya saing perguruan tinggi menunjukkan adanya gejala heterokedasitas yang merupakan dampak dari efek tidak langsung variabel-variabel yang berdampak pada MI terhadap daya saing. Dikarenakan adanya gejala dari heteroskedasitas, maka proses regresi dilakukan dengan metode White.

\section{Hasil Uji Hipotesis}

Hasil uji hipotesis atas faktor-faktor yang berdampak pada pengungkapan modal intelektual dapat disimak pada Tabel 3. Hasil regresi setelah dilakukan pengujian membuktikan bahwa data yang digunakan tidak bias, sebagaimana terangkum dalam Tabel 4. Variabel otonomi, lokasi dan peringkat menunjukkan signifikan dan bertanda positif pada level 10\% dengan masing-masing koefisien 1,38 pada otonomi, 3,9 pada lokasi dan 3,21 pada peringkat/ ranking. Sedangkan umur perguruan tinggi tidak berpengaruh signifikan, karena tingkat probabilitas lebih dari $10 \%$ dan koefisien yang sangat kecil mendekati $0 . R$ Squared menunjukkan angka 0,537, sehingga dapat disimpulkan bahwa otonomi, lokasi dan peringkat mampu berpengaruh pada pengungkapan MI sebesar 53,7\%, sedangkan 46,3\% dipengaruhi variabel lain yang tidak diteliti dalam penelitian ini.

Kesimpulan hasil penelitian adalah semakin besar otonomi yang dimiliki oleh suatu perguruan tinggi, maka akan meningkatkan kemauan perguruan tinggi untuk melakukan pengungkapan MI. Dengan adanya otonomi maka perguruan tinggi memiliki keleluasaan dalam mengelola pendapatannya sehingga mendorong perguruan tinggi berusaha memperoleh dana lebih besar yang dapat diperoleh dari para stakeholders, salah satunya adalah melalui pengungkapan MI. Penelitian ini juga mendukung penelitian Chen dan Chen (2011), bahwa dengan diperolehnya peringkat pada periode sebelumnya meningkatkan kemauan perguruan tinggi untuk melakukan pengungkapan MI. Selain itu, hasil penelitian menunjukkan bahwa perguruan tinggi yang berlokasi di pulau Jawa lebih banyak mengunngkapkan MI daripada perguruan tinggi yang berlokasi di luar pulau Jawa. Sedangkan umur perguruan tinggi tidak mampu berpengaruh terhadap pengungkapan MI.

Tabel 7 menunjukkan hasil regresi dampak pengungkapan MI yang dipengaruhi oleh tingkat otonomi, peringkat sebelumnya, lokasi dan umur perguruan tinggi terhadap daya saing perguruan tinggi. Hasil pengujian menunjukkan bahwa pengungkapan MI berpengaruh signifikan terhadap daya saing perguruan tinggi. Pengungkapan MI berpengaruh $13,4 \%$ terhadap daya saing, sedangkan 86,4\% dipengaruhi oleh variabel lain. 
Tabel 1. Ringkasan Data Pengungkapan MI

\begin{tabular}{lccccc}
\hline Nama Universitas & $\begin{array}{c}\text { Modal } \\
\text { Manusia }\end{array}$ & $\begin{array}{c}\text { Modal } \\
\text { Struktural }\end{array}$ & $\begin{array}{c}\text { Modal } \\
\text { Relasional }\end{array}$ & Total MI & Prosentase \\
\hline Universitas Gadjah Mada & 7 & 14 & 9 & 30 & $65 \%$ \\
Universitas Indonesia & 8 & 17 & 10 & 35 & $76 \%$ \\
Institut Teknologi Bandung & 8 & 16 & 9 & 33 & $72 \%$ \\
Universitas Brawijaya & 8 & 14 & 8 & 30 & $65 \%$ \\
Institut Pertanian Bogor & 6 & 17 & 11 & 34 & $74 \%$ \\
Universitas Sebelas Maret & 4 & 12 & 9 & 25 & $54 \%$ \\
Universitas Diponegoro & 8 & 14 & 9 & 31 & $67 \%$ \\
Universitas Airlangga & 8 & 19 & 8 & 35 & $76 \%$ \\
Universitas Pendidikan Indonesia & 6 & 19 & 8 & 33 & $72 \%$ \\
Universitas Padjadjaran & 7 & 13 & 10 & 30 & $65 \%$ \\
Universitas Gunadarma & 5 & 19 & 6 & 30 & $65 \%$ \\
Institut Teknologi Sepuluh Nopember & 8 & 17 & 9 & 34 & $74 \%$ \\
Universitas Udayana & 7 & 6 & 9 & 22 & $48 \%$ \\
Universitas Negeri Semarang & 5 & 13 & 8 & 26 & $57 \%$ \\
Universitas Negeri Malang & 8 & 9 & 9 & 26 & $57 \%$ \\
Universitas Hasanuddin & 4 & 7 & 9 & 20 & $43 \%$ \\
Universitas Negeri Yogyakarta & 7 & 13 & 11 & 31 & $67 \%$ \\
Universitas Kristen Petra & 8 & 13 & 11 & 32 & $70 \%$ \\
Universitas Riau & 8 & 15 & 5 & 28 & $61 \%$ \\
UIN Syarif Hidayatullah & 8 & 10 & 8 & 26 & $57 \%$ \\
Universitas Bina Nusantara & 7 & 12 & 9 & 28 & $61 \%$ \\
Universitas Muhammadiyah Yogyakarta & 8 & 12 & 8 & 28 & $61 \%$ \\
Universitas Jember & 8 & 16 & 9 & 33 & $72 \%$ \\
Universitas Mercu Buana & 7 & 15 & 8 & 30 & $65 \%$ \\
Universitas Bengkulu & 8 & 8 & 10 & 26 & $57 \%$ \\
Universitas Muhammadiyah Surakarta & 8 & 11 & 9 & 28 & $61 \%$ \\
UIN Maulana Malik Ibrahim & 3 & 11 & 6 & 20 & $43 \%$ \\
UIN Walisongo & 6 & 5 & 5 & 16 & $35 \%$ \\
Universitas Islam Indonesia & 6 & 13 & 11 & 30 & $65 \%$ \\
Universitas Muhammadiyah Malang & 8 & 12 & 7 & 27 & $59 \%$ \\
Universitas Narotama & 7 & 12 & 6 & 25 & $54 \%$ \\
Universitas Syiah Kuala & 8 & 6 & 8 & 22 & $48 \%$ \\
Universitas Sriwijaya & 7 & 8 & 7 & 22 & $48 \%$ \\
Universitas Sumatera Utara & 6 & 13 & 6 & 25 & $54 \%$ \\
Universitas Esa Unggul & 7 & 15 & 4 & 26 & $57 \%$ \\
\hline & & & & &
\end{tabular}

Tabel 2. Statistik Deskriptif

\begin{tabular}{lcccccc}
\hline & COMP & DISCMI & RANK & OTO & AGE & LOC \\
\hline Mean & 1.285714 & 27.91429 & 0.285714 & 0.914286 & 49.48571 & 0.800000 \\
Median & 0.000000 & 28.00000 & 0.000000 & 1.000000 & 54.00000 & 1.000000 \\
Maximum & 9.000000 & 35.00000 & 1.000000 & 2.000000 & 70.00000 & 1.000000 \\
Minimum & 0.000000 & 16.00000 & 0.000000 & 0.000000 & 11.00000 & 0.000000 \\
Std. Dev. & 2.584700 & 4.635994 & 0.458349 & 0.853072 & 13.40406 & 0.405840 \\
Skewness & 1.856896 & -0.501673 & 0.948683 & 0.162687 & -1.186368 & -1.500000 \\
Kurtosis & 5.059677 & 2.773629 & 1.900000 & 1.433127 & 3.880528 & 3.250000 \\
Jarque-Bera & 26.30035 & 1.542840 & 7.014583 & 3.734733 & 9.340919 & 13.21615 \\
Probability & 0.000002 & 0.462356 & 0.029978 & 0.154530 & 0.009368 & 0.001349 \\
Sum & 45.00000 & 977.0000 & 10.00000 & 32.00000 & 1732.000 & 28.000000 \\
Sum Sq. Dev. & 227.1429 & 730.7429 & 7.142857 & 24.74286 & 6108.743 & 5.600000 \\
\hline Observations & 35 & 35 & 35 & 35 & 35 & 35 \\
\hline
\end{tabular}

Hasil regresi tersebut mendukung penelitian yang dilakukan oleh Lin et al. (2014) yang menyatakan bahwa MI mampu mengkomunikasikan sumber daya yang dimiliki organisasi sehingga meningkatkan pengetahuan pihak yang berkepentingan atas keunggulan yang dimiliki oleh perguruan tinggi. Dengan pengetahuan akan sumber daya PT terutama MI, akan menarik pihak yang 
berkepentingan untuk bekerjasama dengan PT sehingga daya saing PT meningkat, yang terukur dari semakin baik peringkat yang diperoleh oleh PT.

Tabel 3. Hasil Regresi 1

\begin{tabular}{lcc}
\hline \multicolumn{1}{c}{ Variable } & Coefficient & Prob. \\
\hline OTO & 1.380 & 0.09 \\
LOC & 3.906 & 0.016 \\
RANK & 3.208 & 0.036 \\
AGE & 0.065 & 0.178 \\
C & 19.413 & 0.000 \\
\hline R-squared & & 0.538 \\
Adjusted R-squared & & 0.476 \\
Prob(F-statistic) & & 0.0000 \\
\hline
\end{tabular}

Dependent Variable: DISCMI

Method: Least Squares

Sample: 135

\section{Tabel 4. Hasil Regresi 2}

\begin{tabular}{lcc}
\hline \multicolumn{1}{c}{ Variable } & Coefficient & Prob. \\
\hline C & -13.731 & 0.000 \\
DISCMI & 0.538 & 0.000 \\
R-squared & & 0.134 \\
Adjusted R-squared & & 0.108 \\
Prob(F-statistic) & & 0.000 \\
\hline
\end{tabular}

Dependent Variable: COMP

Method: Two-Stage Least Squares

Sample: 135

Instrument list: RANK OTO AGE LOC

\section{SIMPULAN}

Penelitian ini menyimpulkan bahwa pengungkapan MI pada perguruan tinggi di Indonesia dipengaruhi oleh tingkat otonomi dan peringkat yang diperoleh perguruan tinggi sebelumnya. Selain itu faktor lokasi terbukti berdampak signifikan dalam pengungkapan MI, yang berarti bahwa dalam lingkungan yang lebih tinggi persaingannya, maka kemauan perguruan tinggi dalam melakukan pengungkapan semakin besar. Sedangkan umur perguruan tinggi tidak berpengaruh dalam pengungkapan MI. Secara praktik, penelitian berkontribusi bagi regulator dengan informasi bahwa otonomi yang diberikan kepada perguruan tinggi berperan dalam meningkatkan pengungkapan MI yang selanjutnya berdampak terhadap peningkatan daya saing PT. Selain itu, bagi penelitian ini berkontribusi bagi praktisi di perguruan tinggi, bahwa peningkatan daya saing perguruan tinggi dapat dicapai melalui pengungkapan MI. Secara teoritis, penelitian ini mampu membuktikan secara empiris bahwa otonomi dan peringkat yang diperoleh sebelumnya berperan dalam meningkatkan pengungkapan MI, selain itu pengungkapan MI secara empiris mampu meningkatkan daya saing perguruan tinggi.

Keterbatasan penelitian ini adalah angka $R$ Square yang rendah menunjukkan bahwa terdapat variabel lain yang berpengaruh akan tetapi tidak dimasukkan dalam penelitian. Selain itu, jumlah sampel yang digunakan masih terlalu kecil jika dibandingkan dengan banyaknya perguruan tinggi yang ada di Indonesia. Saran bagi penelitian selanjutnya adalah proses penelaahan komponen MI pada situs resmi perguruan tinggi dilakukan lebih dari satu orang, menggunakan pengungkapan berdasarkan sumber tertulis, misalnya laporan tahunan perguruan tinggi dan melakukan pengujian variabel baru yang diperoleh melalui pengkajian yang lebih mendalam serta penambahan jumlah sampel penelitian. Selain itu, penelitian MI di perguruan tinggi juga penting untuk dilakukan dengan menguji pengaruhnya terhadap variabel lain, seperti kualitas perguruan tinggi yang dilihat dari akreditasi agar dapat ditemukan bukti tambahan apakah MI memang memberikan manfaat bagi perguruan tinggi atau tidak.

\section{DAFTAR PUSTAKA}

Artiah, B. 2013. Faktor-Faktor yang Mempengaruhi Pengungkapan Intellectual Capital pada Lem-baga Keuangan yang Terdaftar di Bursa Efek Indonesia. Jurnal Kopertis, 5, 45-56.

Bornemann, M., dan K. Leitner. 2002. Measuring and reporting intellectual capital: The case of a research technology organisation. Singapore Management Review, 24 (3), 7 19.

Bryson, J. M. 2011. Strategic Planning for Publlic and Non Profit Organization (4e ed.). San Fransisco: Jhon Wiley \& Sons.

Chen, I., dan J. Chen. 2013. Present and future: A trend forecasting and ranking of university types for innovative development from an intellectual capital perspective. Quality and Quantity, 47 (1), 335-352.

Connelly, B. L., S. T. Certo, R. D. Ireland, dan C. R. Reutzel. 2011. Signaling Theory: A Review and Assessment. Journal of Management, 39-67.

Constantine. 2005. The Intellectual Capital of Universities. Bucharest: Academy of Economic Studies. 
Corcolez, Y. R., S. J. Penalver, dan T. P. Angel. 2011. Intellectual capital in spanish public universities: Stakeholders' information needs. Journal of Intellectual Capital, 12 (3), 356-376.

Debreceny, R., G. L. Gray, dan A. Rahman. 2002. The Determinants of Internet Financial Reporting. Journal of Accounting and Public Policy, 21, 371-394.

Fazlagic, J., dan R. Skikiewicz. 2014. The Role of Intellectual capital in Building Competitive Advantage of Non-Public Universities. 547556.

Holmen, J. 2011. Using Intellectual Capital Disclo-sure as A Framework for Non Financial Disclosures : The Danish Experience. Acade-my od Accounting and Financial Studies Journal, 15 (4), 141-154.

Kompas. 2015. Edukasi. Retrieved Oktober 13, 2016, from kompas.com. http://edukasi.kompas.com/read/2015/11/1 7/07090891/PR.Besar.Di.Luar.Jawa.Hanya. Dua.Universitas.yang.Berakreditasi.A.

Leandro, dan P. M. Sanchez. 2009. Intangibles in Universities: Current Challenges for Measuring and Reporting. Journal of HRCA: Human Resource Costing \& Accounting, 13 (2), 93-104.

Leitner, K., M. Schaffhauser-Linzatti, R. Stowasser, dan K. Wagner. 2005. Data envelopment analysis as method for evaluating intellectual capital. Journal of Intellectual Capital, 6 (4), 528-543.

Lin, L.-S., I.-C. Huang, P.-L Du, dan T.-F Lin. 2012. The moderating effects of knowledge intensity and organizational size. Management Decision, 50 (10), 1790-1799.

Meilianti, dan D. Frisko. 2013. Dinamika Pengelolaan Intellectual Capital pada Institusi Pen-didikan di Surabaya. Jurnal Ilmiah Mahasiswa Universitas Surabaya, 2 (2).

Pratiwi, R. Y. 2012. Analisis Praktik Pengungkapan Intellectual Capital pada Website Universitas Peraih QS-Star 2011. Jurnal Reviu Akuntansi dan Keuangan, 2 (2), 127139.

Ramirez, Y., dan S. Gordillo. 2014. Recognition and measurement of intellectual capital in spanish universities. Journal of Intellectual Capital, 15 (1), 179-188.

Ramirez, Y., A. Tejada, dan A. Baidez. 2013. Proposal of indicators for reporting on intellectual capital in universities. Paper presented at the $355-\mathrm{XV}$.
Sánchez, M. P., S. Elena, dan R. Castrillo. 2009. Intellectual Capital Dynamics in Universities: A Reporting Model. Journal of Intellectual Capital, 10 (2), 307-324.

Septiana, G. R., dan N. E. Yuyetta. 2013. Analisis Faktor-Faktor yang Mempengaruhi Pengungkapan Intellectual Capital pada Prospektus IPO. Diponegoro Journal of Accounting, 2 (3), 189-203.

Sonnier, B. M., K. D. Carson, dan P. P. Carson. 2009. An examination of the impact of firm size and age on managerial disclosure of intellectual capital by high-tech companies. Journal of Bussiness Strategies, 26 (2), 223245.

Ulum, I. 2012. Konstruksi Komponen Intellectual Capital Untuk PerguruanTinggi di Indonesia. Jurnal Reviu Akuntansi dan Keuangan, 2 (2), 251-262.

Ulum, I., dan N. Novianty. 2012. Analisis FaktorFaktor yang Mempengaruhi Pengungkapan Intellectual Capital pada Official Website Perguruan Tinggi Indonesia. ASP Trunojoyo.

Undang-Undang No 12 Tahun 2012 tentang Pendidikan Tinggi.

Widyaningdyah, A. U. dan Y. Aryani. 2013. Intellectual Capital dan Keunggulan Kompetitif. Jurnal Akuntansi dan Keuangan, 15 (1), 114. 